\title{
Influence of Calcined Clay Reactivity on the Mechanical Properties and Chloride Diffusion Resistance of Limestone Calcined Clay Cement (LC3) Concrete
}

\author{
Quang Dieu Nguyen ${ }^{1, * \mathbb{D}}$, Sumaiya Afroz ${ }^{2}$ and Arnaud Castel ${ }^{1}$ \\ 1 School of Civil and Environmental Engineering, University of Technology Sydney (UTS), Sydney, \\ NSW 2007, Australia \\ 2 Centre for Infrastructure Engineering and Safety, School of Civil and Environmental Engineering, University \\ of New South Wales, Sydney, NSW 2052, Australia \\ * Correspondence: quangdieu.nguyen@uts.edu.au
}

Received: 24 March 2020; Accepted: 22 April 2020; Published: 25 April 2020

\begin{abstract}
Calcined clay plays an important role in the performance of limestone calcined clay cement (LC3) concrete. In this study, the performance of two different types of calcined clay produced from different calcination processes were investigated in chloride environment. The characteristics of the calcined clays, including mineral composition, chemical composition, particle size distribution, specific surface area and particle morphology, were evaluated. Based on the reactivity of the calcined clays, the compressive strength of concretes after up to 28 days of curing was adopted as the best measure to determine the appropriate replacement levels of Portland cement by LC3 to satisfy standards requirements for concrete in chloride environments. The chloride bulk diffusion test was conducted to investigate the performance of LC3 concretes in comparison with reference Portland cement concrete. Similar chloride diffusion resistance could be achieved by using the two different calcined clays in LC3 concrete. The performance of both LC3 concretes was much better than that of reference concrete. However, the Portland cement substitution rate for each calcined clay was governed by the compressive strength standard requirements.
\end{abstract}

Keywords: LC3; calcined clay; limestone; low-carbon concrete; chloride diffusion

\section{Introduction}

Concrete and other cementitious materials play a decisive role in the global economy and human society. Across the world, concrete is the second most consumed substance after water [1-3]. With the world population predicted to be over 9 billion in 2050 [4], concrete will still be the most-in-demand element to fulfil the substantial expansion of infrastructure and housing in modern societies, especially in developing countries such as China and India. In addition, the continual ageing of concrete structures in industrialised countries has also been producing additional cost [5]. For instance, an increasing number of bridges have to be utilised beyond their design life of 50 years, which leads to additional cost to keep these structures serviceable [6]. All of these things result in high cost to society, mostly due to chloride-induced reinforcement corrosion of concrete structures [7]. The chloride diffusion process is critical for the durability of marine concrete structures. Chloride ions penetrate through concrete porosity and accumulate at the steel-concrete interface [8]. When the chloride content at the steel depth reaches the so-called chloride threshold, reinforcement is depassivated and the corrosion propagation stage starts leading to a time-dependent steel cross section reduction, expansive corrosion products formation, and subsequently concrete cracking, as well as spalling of marine structures (Figure 1). 


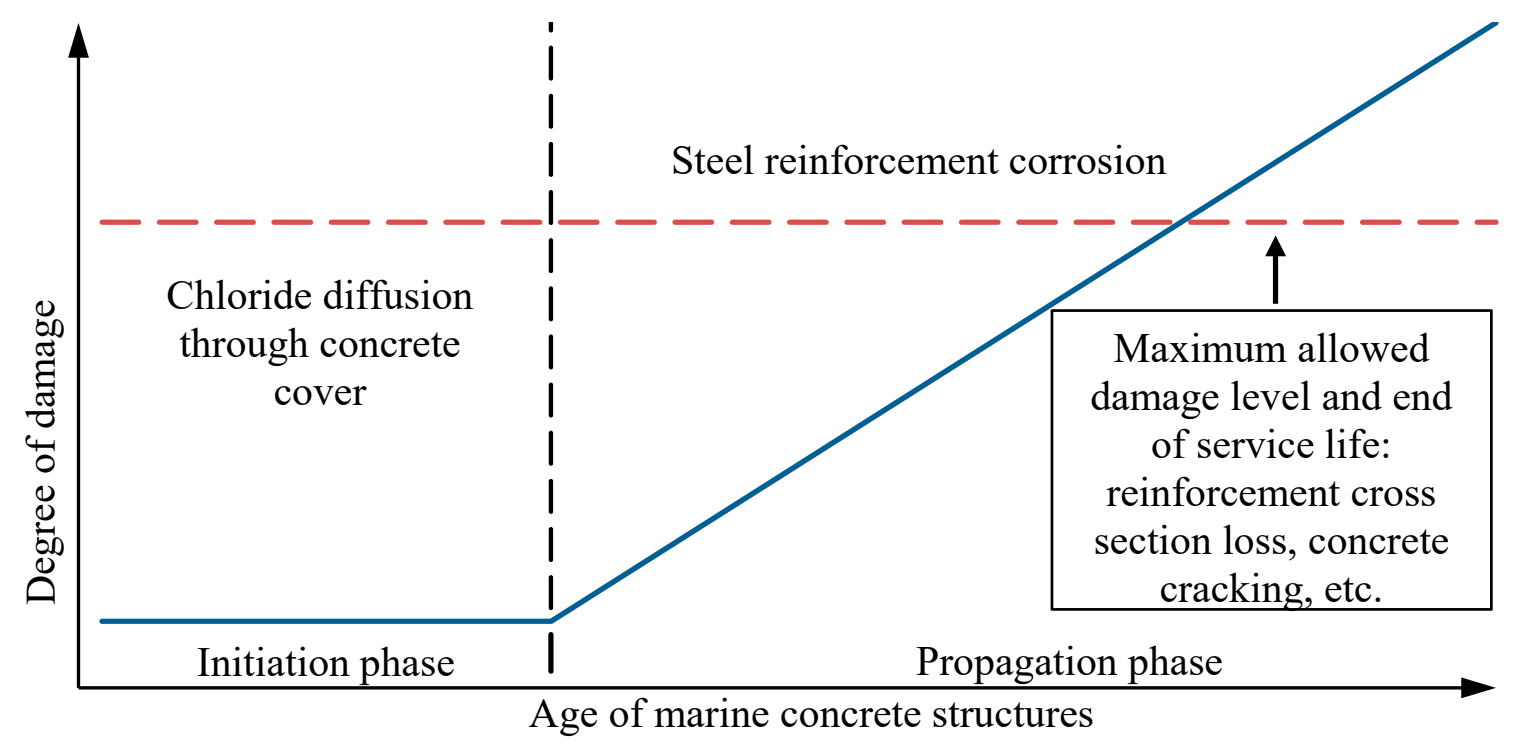

Figure 1. Chloride induced corrosion process of marine concrete structures (Adapted from [7]).

The concrete industry has been urged to reduce its impact on the environment [9]. Decarbonation of limestone for producing clinker, the main component of Portland cement, generates $60 \%$ of the $\mathrm{CO}_{2}$ emissions of cement manufacture. In addition, no promising alternative to limestone has been proposed for cement production. Possible approaches to be carbon neutral are $\mathrm{CO}_{2}$ capture and storage (CCS) or Belite-Ye'elimite-Ferrite (BYF) clinkers (e.g. "Aether" or "Ternocem") but these approaches face various technical limits and expensive cost $[1,9,10]$. Another feasible method to minimise $\mathrm{CO}_{2}$ emission is substitution of Portland cement by using supplementary cementitious materials (SCMs). One of the emerging SCMs which has been attracted worldwide attention is the combination of calcined clay and limestone. This can be mainly attributed to the global availability of calcined clay and limestone [11]. Moreover, suitable clays for use as raw materials for calcined clays are currently considered waste material at existing quarries providing clay for the ceramic industries $[1,11]$. The utilization of these clays can significantly increase the global supply of calcined clays, but also prevent the exploitation of natural clay resources. Calcined clay is a reactive SCM as a result of large amorphous reactive phases content produced by calcining kaolinitic clay to around $700{ }^{\circ} \mathrm{C}-850^{\circ} \mathrm{C}$ and limestone only requires grinding, which demonstrates significant energy and $\mathrm{CO}_{2}$ emission reduction compared to conventional Portland cement production [12-15]. Calcined clay, limestone and Portland cement blend has been denoted as limestone calcined clay cement (LC3). In addition, the production cost of LC3 is $15 \%-25 \%$ lower than that of conventional blended cement [16], which indicates the remarkable potential for industry adoption. The hydration process and mechanical properties of LC3 materials have been reported in previous studies [17-20]. Antoni et al. [17] first revealed the synergistic effects of calcined clay and limestone to produce mono/hemicarboaluminate, which are beneficial to the early strength of mortar. Subsequently, different properties of LC3-based materials were investigated to accelerate the adoption by the construction industry $[16,21-27]$. The durability properties of mortars and concretes containing calcined clay and limestone in chloride environments were investigated in previous studies [28-32]. It is widely acknowledged that LC3 can improve the resistance of concrete against chloride penetration in comparison with Portland cement concrete. In addition, the different calcination processes lead to different characteristics of calcined clay, which influence their performance as SCM [33-36]. Consequently, the influence of calcined clay characteristics on the optimum replacement level of Portland cement and on chloride diffusion resistance has not been fully evaluated. In this study, the effect of calcined clays on the chloride diffusion resistance of concrete, which governs the durability properties of marine concrete structures, were evaluated. Two different calcined clays produced from different calcination processes were investigated. The characteristics 
of calcined clays were first evaluated by using X-ray fluorescence (XRF), X-ray diffraction (XRD), laser diffraction, a gas sorption analyser and a scanning electron microscope (SEM). Due to their different reactivity, appropriate replacement rates of Portland cement were selected to satisfy the Australian standard AS 3600 [37] requirement for compressive strength aftter 28 days of curing. The time-dependent mechanical properties of concrete including compressive strength and elastic modulus up to 28 days were measured. The performance of LC 3 concretes with different calcined clays against chloride diffusion was investigated by using the chloride bulk diffusion test. The influence of calcined clay types on the chloride diffusion resistance was evaluated and compared to Portland cement concrete without using LC3.

\section{Materials and Methodology}

\subsection{Materials, Concrete Mix Design and Curing Condition}

General purpose cement (GPC), calcined clay and limestone as a binder were used to fabricate LC3 concrete. According to Australian Standard AS 3792 [38], GPC comprises 90wt.\% (percentage by mass) of ordinary Portland clinker, $7 w t . \%$ to $8 w t . \%$ of mineral addition and $2 w t . \%$ to $3 w t . \%$ of gypsum. Two calcined clays were produced by industrial processes. Specifically, the first calcined clay was produced by flash calcination and the second by rotary kiln calcination process, denoted as flash calcined clay and rotary kiln calcined clay respectively. The flash and rotary kiln calcination were described in a previous study [13]. The detailed characteristics of the two calcined clays are presented in Section 2.2. The chemical composition of GPC, calcined clays and limestone analysed by X-ray fluorescence (XRF) are shown in Table 1. Sydney sand and basalt with $10 \mathrm{~mm}$ nominal size were utilised as fine and coarse aggregate respectively. Depending on calcined clay reactivity, different rates of replacement of GPC were determined to achieve a compressive strength after 28 days higher than $45 \mathrm{MPa}$, to fulfil the Australian Standard AS 3600 [37] requirement for chloride environments. The substitution rate was $20 \mathrm{wt} . \%$ of binder in LC3 concrete with flash calcined clay (LC3-F concrete) whilst the replacement rate was $44 \mathrm{wt} . \%$ in LC3 concrete with rotary kiln calcined clay (LC3-R concrete). A Portland cement replacement rate by flash calcined clay and limestone higher than $20 \mathrm{wt} . \%$ could drastically decrease the concrete compressive strength according to a previous study by the authors [18]. The substitution level of rotary kiln calcined clay and limestone at $44 \mathrm{wt} . \%$ was selected based on a preliminary unpublished work by the authors. The ratio of calcined clay and limestone by mass was 2:1. The reference concrete without calcined clay and limestone was labelled GPC. Table 2 presents the details of concrete mix proposition with all aggregate in saturated surface dry (SSD) condition. Prior to concrete casting, all aggregates were dried at $105^{\circ} \mathrm{C}$ in an oven for $24 \mathrm{~h}$ to remove remaining moisture. Subsequently, they were cooled down in an ambient environment and calculated SSD water amount was added to ensure the SSD condition of aggregates.

Table 1. Chemical compositions of binder. GP cement: general purpose cement.

\begin{tabular}{ccccc}
\hline $\begin{array}{c}\text { Chemical } \\
\text { Composition (wt.\%) }\end{array}$ & GP Cement & Limestone & $\begin{array}{c}\text { Flash Calcined } \\
\text { Clay }\end{array}$ & $\begin{array}{c}\text { Rotary Kiln } \\
\text { Calcined Clay }\end{array}$ \\
\hline $\mathrm{SiO}_{2}$ & 19.74 & 0.36 & 70.42 & 48.15 \\
$\mathrm{Al}_{2} \mathrm{O}_{3}$ & 4.70 & 0.11 & 22.34 & 41.63 \\
$\mathrm{Fe}_{2} \mathrm{O}_{3}$ & 2.98 & 0.1 & 2.34 & 2.27 \\
$\mathrm{CaO}$ & 64.62 & 57.51 & 0.49 & 0.12 \\
$\mathrm{MgO}$ & 1.48 & 0.29 & 0.16 & 0.09 \\
$\mathrm{Na}_{2} \mathrm{O}$ & 0.21 & - & 0.1 & 0.32 \\
$\mathrm{~K}_{2} \mathrm{O}$ & 0.64 & - & 0.19 & 0.05 \\
$\mathrm{TiO}_{2}$ & 0.31 & - & 1.1 & 3.39 \\
$\mathrm{SO}_{3}$ & 2.24 & - & 0.02 & 0.09 \\
\hline Loss on ignition (LOI) & 3.18 & 42.61 & 1.76 & 3.21 \\
\hline
\end{tabular}


Table 2. Mix compositions. GPC: general purpose cement; LC3-F: limestone calcined clay cement (LC3) concrete with flash calcined clay; LC3-R concrete: LC3 concrete with rotary kiln calcined clay.

\begin{tabular}{cccc}
\hline Materials $\mathbf{( k g )}$ & GPC & LC3-F & LC3-R \\
\hline Coarse aggregate & 1221 & 1221 & 1201.5 \\
Fine aggregate & 620.8 & 620.8 & 610.9 \\
\hline Total binder & 388 & 388 & 388 \\
\hline GPC & 388 & 310.4 & 217.3 \\
Flash calcined clay & 0 & 50.44 & 0 \\
Rotary kiln calcined clay & 0 & 0 & 116.4 \\
Limestone & 0 & 27.16 & 54.3 \\
\hline Water/binder ratio & 0.45 & 0.45 & 0.45 \\
Water & 174.5 & 174.5 & 174.5 \\
\hline
\end{tabular}

Aggregates and binder were first dry mixed for $2 \mathrm{~min}$ and then water was added mixed for another $5 \mathrm{~min}$. Fresh concrete was poured into poured into $100 \mathrm{~mm} \times 200 \mathrm{~mm}$ cylinders moulds in two layers and a vibrating table was used to compact concrete and remove entrapped air. All cylinders were covered by lids to prevent surface moisture loss. After 1 day, all concrete specimens were demoulded and placed continuously into a water bath for 7 days, except for specimens tested before 7 days. They were then removed from the water bath and stored in a controlled room with the temperature of $23 \pm 2{ }^{\circ} \mathrm{C}$ and relative humidity $(\mathrm{RH})$ of $50 \%$ until testing.

\subsection{Characteristics of Calcined Clay}

As the aim of this study was to investigate the influence of calcined clay reactivity on concrete performance in a chloride environment, two types of calcined clay were considered. The chemical composition was determined by using the X-ray fluorescence (XRF) method. X-ray diffraction (XRD) was carried out to investigate crystalline phases of calcined clay by using a PANalytical X'Pert PRO multi-purpose $\mathrm{X}$-ray diffraction system. The system configuration was $\mathrm{Cu}-\mathrm{K} \alpha$ radiation with a wavelength of $0.15418 \mathrm{~nm}$ and a fixed divergence slit size of $0.5^{\circ}$, the operation with $45 \mathrm{kV}$ and $40 \mathrm{~mA}$, scan range $5-70^{\circ}$ and $0.013^{\circ} 2 \theta$ step size. Moreover, the quantification of crystalline phases in calcined clays was determined by using XRD-Rietveld with crystalline $S i$ as an internal standard [27]. Raw data collected were processed by High Score Plus software (supplier PANalytical). A search match of candidate crystalline phases was performed using the Powder Diffraction File (PDF) 4+ database followed by Rietveld refinement in order to quantify the crystalline phases.

The particle size distribution (PSD) was measured using the laser diffraction technique with a Malvern Mastersizer instrument. The surface area was measured by the Blaine method and the Brunauer-Emmett-Teller (BET) technique using a NOVAtouch gas sorption analyser.

The morphological properties of calcined clay particles were analysed using a Hitachi S-3400N scanning electron microscope (SEM). The samples were prepared using the gold coating technique. The test was carried out in backscattered electron imaging mode with a working voltage of $20 \mathrm{kV}$ and probe current of $50 \mathrm{~mA}$ under a high vacuum condition.

\subsection{Mechanical Properties of LC3 Concrete}

The compressive strength of concrete cylinders was measured after 1, 3, 7, 14, 21 and 28 days of curing, using three cylinders according to American Society for Testing and Materials (ASTM) C39 [39]. The elastic modulus was determined at 28 days, following standard ASTM C469 [40]. 


\subsection{Bulk Diffusion Test}

The bulk diffusion test was conducted in accordance with the ASTM C1556 [41] test protocol. The concrete cylinders were cut into concrete discs with $100 \mathrm{~mm}$ in diameter and $75 \mathrm{~mm}$ in height after 28 days of curing. The concrete discs were then vacuum-saturated in water. After $24 \mathrm{~h}$ of immersion, the discs were sealed with self-adhesive foils, except the surface exposed to sodium chloride solution before vacuum saturation again. Subsequently, the specimens were placed into $16.5 \% \mathrm{NaCl}$ solution for 35 days. After completing the exposure duration, the concrete powder was obtained at every $1 \mathrm{~mm}$ depth from the exposure surface to $25 \mathrm{~mm}$ of depth by using a profile grinder. The powder was stored separately in plastic vials for chloride content analysis.

The total chloride content in concrete powder was measured by using the test method for acid-soluble chloride following ASTM C1152 [42] and presented as the mass percentage over the concrete powder. $3.5 \mathrm{~g}$ of concrete powder was dispersed with $10 \mathrm{~mL}$ distilled water and $20 \mathrm{~mL}$ of $20 \%$ concentration dilute acid was then added to the solution. $1 \mathrm{~mL}$ of hydrogen peroxide solution was added to the solution, as recommended in ASTM C1152, to prevent the interference of sulphide in the test results. The solution was placed into an ultrasonic bath for $15 \mathrm{~min}$ at $60{ }^{\circ} \mathrm{C}$ and then cooled down in an ambient environment for $2 \mathrm{~h}$ [43]. Subsequently, the solution was filtered using filter paper, a Buchner funnel, a filtration flask and a vacuum pump. Distilled water was rinsed to collect the remaining solution inside the flask. Approximately $60 \mathrm{~mL}$ of the final solution was then analysed in a potentiometric titration machine using silver nitrate solution to measure the total chloride content.

The apparent chloride diffusion coefficient was derived from the plot of total chloride content against exposure depth by means of a non-linear regression analysis with the least square method, as presented in Equation (1):

$$
C(x, t)=C_{s}-\left(C_{s}-C_{i}\right) \times \operatorname{erf}\left(\frac{x}{\sqrt{4 \times D_{a} \times t}}\right)
$$

where:

$C(x, t)$ : the chloride concentration, measured at depth $x$ and exposure time $t$ in $w t . \%$

$\mathrm{C}_{\mathrm{s}}$ : the chloride concentration at the exposure surface which is determined by the regression analysis in wt.\%

$\mathrm{C}_{\mathrm{i}}$ : initial chloride-ion concentration in the concrete before submersion in the $\mathrm{NaCl}$ solution in wt. $\%$

$\mathrm{x}$ : the depth below the exposed surface (to the middle of a layer) in $\mathrm{m}$

$\mathrm{D}_{\mathrm{a}}$ : the apparent chloride diffusion coefficient in $\mathrm{m}^{2} / \mathrm{s}$

t: the exposure time in second

erf: the error function as shown in Equation (2):

$$
\operatorname{erf}(z)=\frac{2}{\sqrt{\pi}} \int_{0}^{z} \exp \left(-u^{2}\right) d u
$$

\section{Results and Discussion}

\subsection{Characteristics of Calcined Clays}

The crystalline phases of calcined clays and their quantity are presented in Figure 2 and Table 3, respectively. Quartz was the only crystalline phase in flash calcined clay, whilst rotary kiln calcined clay contained anatase, dickite, kaolinite, mullite and quartz. From the XRD-Rietveld results, a high amount of quartz was observed in flash calcined clay, $49.1 \mathrm{wt} . \%$ in comparison with $2 \mathrm{wt} . \%$ in rotary kiln calcined clay. The quantification of quartz was consistent with the chemical composition analysed by XRF. $\mathrm{SiO}_{2}$ constituted around $70 \mathrm{wt} . \%$ in flash calcined clay whilst it presented at about $48 \mathrm{wt} . \%$ in rotary kiln calcined clay according to XRF analysis. By contrast, the $\mathrm{Al}_{2} \mathrm{O}_{3}$ content in rotary kiln calcined clay was approximately twice that of flash calcined clay. The amorphous content of calcined clay was used 
as an indicator for their reactivity. Flash and rotary kiln calcined clays in this study were classified as low-grade and medium-grade calcined clay respectively, with amorphous contents of $50.9 \mathrm{wt} . \%$ and $78.8 \mathrm{wt} . \%[18,44,45]$. The combination of mullite, dickite, kaolinite and anatase represented around $19 \mathrm{wt} . \%$ of rotary kiln calcined clay. The presence of kaolinite indicated that the calcination process was not entirely completed in the rotary calcined clay whereas the flash calcined clay showed the absence of kaolinite in the crystalline phases.
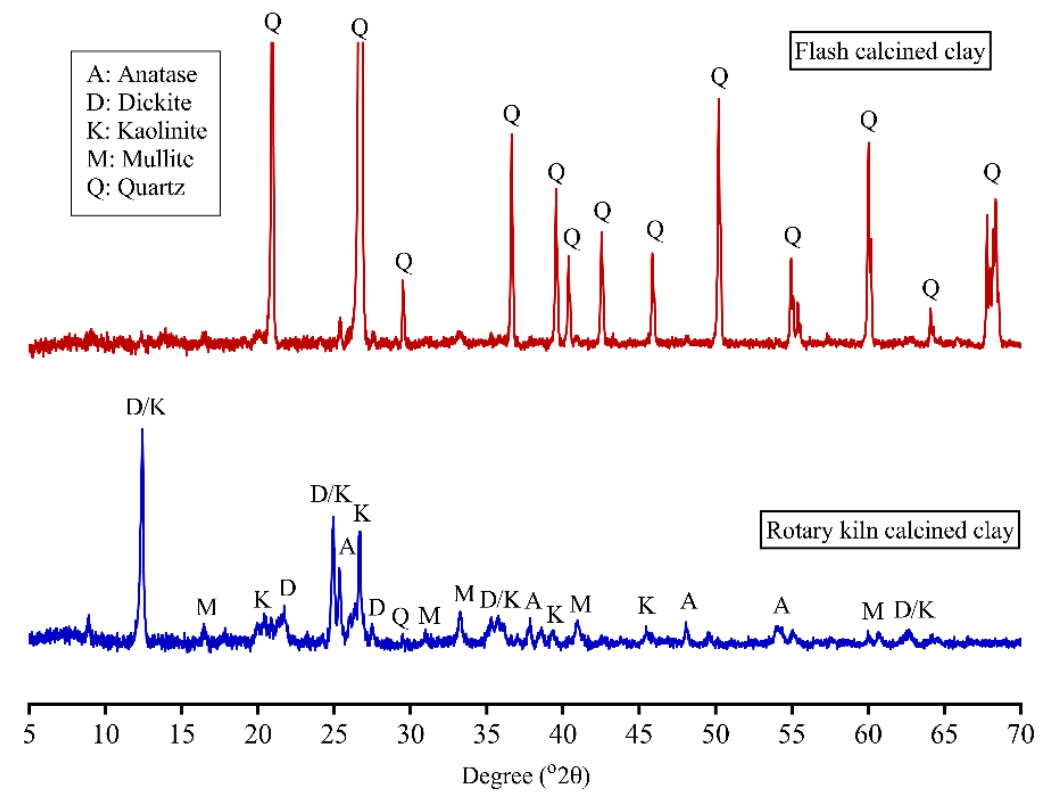

Figure 2. X-ray diffraction (XRD) patterns of calcined clays.

Table 3. Mineral composition and specific surface area of calcined clays.

\begin{tabular}{ccc}
\hline Minerals (wt.\%) & Flash Calcined Clay & Rotary Kiln Calcined Clay \\
\hline Quartz & $49.1 \pm 0.1$ & $2.0 \pm 0.1$ \\
Mullite & - & $6.4 \pm 0.2$ \\
Dickite & - & $7.3 \pm 0.2$ \\
Kaolinite & - & $4.1 \pm 0.1$ \\
Anatase & $50.9 \pm 0.1$ & $1.5 \pm 0.1$ \\
Amorphous & & $78.8 \pm 0.1$ \\
\hline Particle size distribution $(\mu \mathrm{m})$ & 2.50 & \\
\hline $\mathrm{D}_{\mathrm{v} 10}$ & 21.19 & 3.85 \\
$\mathrm{D}_{\mathrm{v} 50}$ & 64.75 & 14.40 \\
$\mathrm{D}_{\mathrm{v} 90}$ & $12.05 \pm 0.01$ & 43.37 \\
\hline BET surface area $\left(\mathrm{m}^{2} / \mathrm{g}\right)$ & & \\
\hline
\end{tabular}

The particle size distributions of the two calcined clays are reported in Figure 3 and Table 3. Flash calcined clay showed more particles less than $10 \mu \mathrm{m}$, whereas rotary kiln calcined clay obtained higher cumulative particles passing from $10 \mu \mathrm{m}$ to $100 \mu \mathrm{m} . \mathrm{D}_{\mathrm{v} 10}, \mathrm{D}_{\mathrm{v} 50}$ and $\mathrm{D}_{\mathrm{v} 90}$ are defined as the points in the particle size distribution from laser diffraction at which $10 \%, 50 \%$ and $90 \%$ respectively of the total volume of material in the sample are accumulated (Table 3). Flash calcined clay presented a lower $D_{v 10}$ and higher $D_{v 50}$ and $D_{v 90}$ in comparison with rotary kiln calcined clay. Both calcined clays were classified as coarse calcined clay [25] and fulfil the fineness requirement which is less than $34 \mathrm{wt} . \%$ of particle retained on $45 \mu \mathrm{m}$ sieve for using as SCM in concrete product following ASTM C618 [46]. The BET surface area of flash calcined clay was $12.05 \mathrm{~m}^{2} / \mathrm{g}$, which is higher than that of rotary kiln calcined clay of $8.8 \mathrm{~m}^{2} / \mathrm{g}$. 


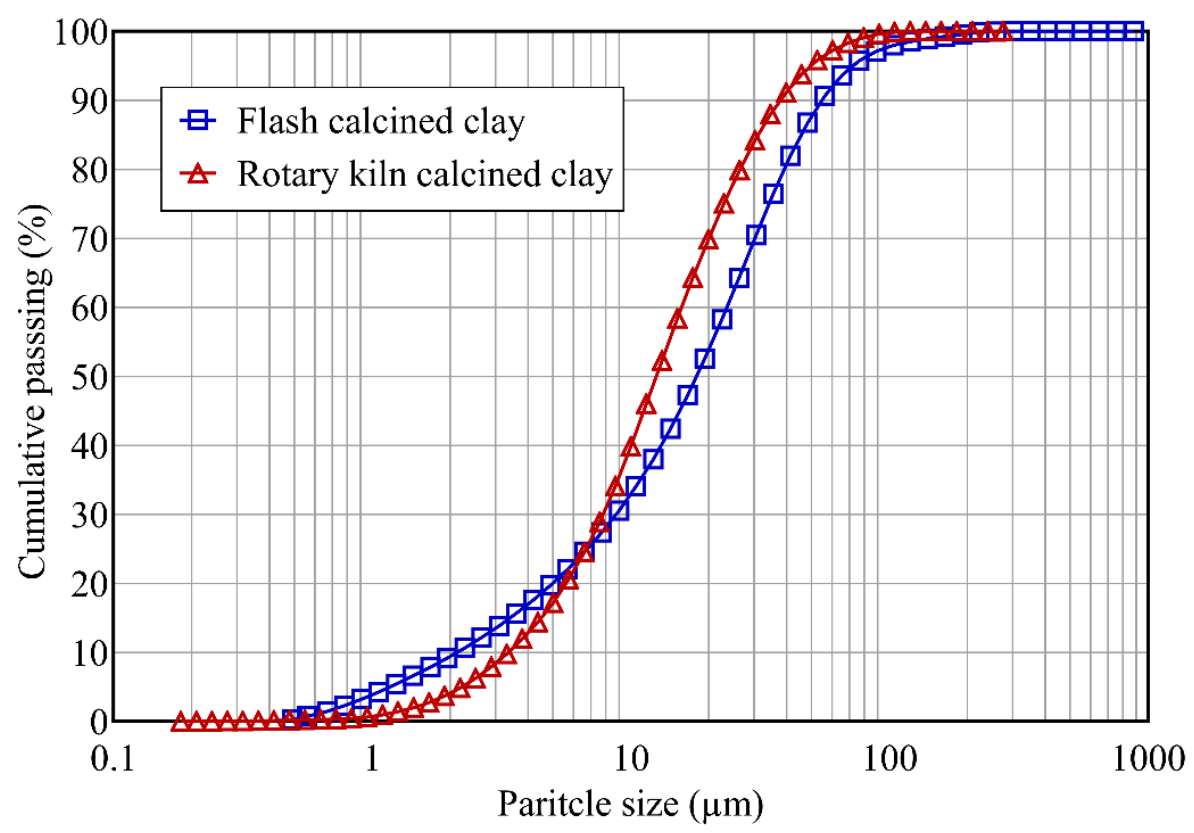

Figure 3. Particle size distribution of calcined clays.

The morphology of calcined clays particles is presented in Figure 4 at different magnifications [18]. No difference was observed between calcined clays under low magnification (Figure $4 a, c)$. In Figure $4 b, d$, with high magnification, both flash and rotary calcined clays presented a predominant presence of pseudo hexagonal plates and cluster of plates $[13,18,33,47]$. Noticeably, spherical particles with sizes between 5 to $10 \mu \mathrm{m}$ were only detected in flash calcined clay. Previous studies reported that flash calcined clay could contain from $10 \%$ to $20 \%$ spherical particles [13,47]. This can be attributed to the different calcination process. In flash calcination, the clay particles near the flame experience a vitrification of submicron aluminium silicates, producing droplets to minimise the surface energy. As a result, spherical particles mainly contain amorphous aluminium silicates and trace amount of crystallised and pure aluminium silicates [47]. During the cooling step of flash calcination, the submicron metakaolinite particles adhere on the spherical particles surface [47], which is showed in Figure 4d. Fly ash is also composed mainly spherical particles, and is produced through a similar process [48-50]. The plate shape of particles might result in the overestimation of PSD and BET surface area in both flash and rotary kiln calcined clay. This was attributed to the inappropriate assumption of a spherical rather than plate-like shape for analysing data from the laser diffraction and gas adsorption technique [51,52]. 

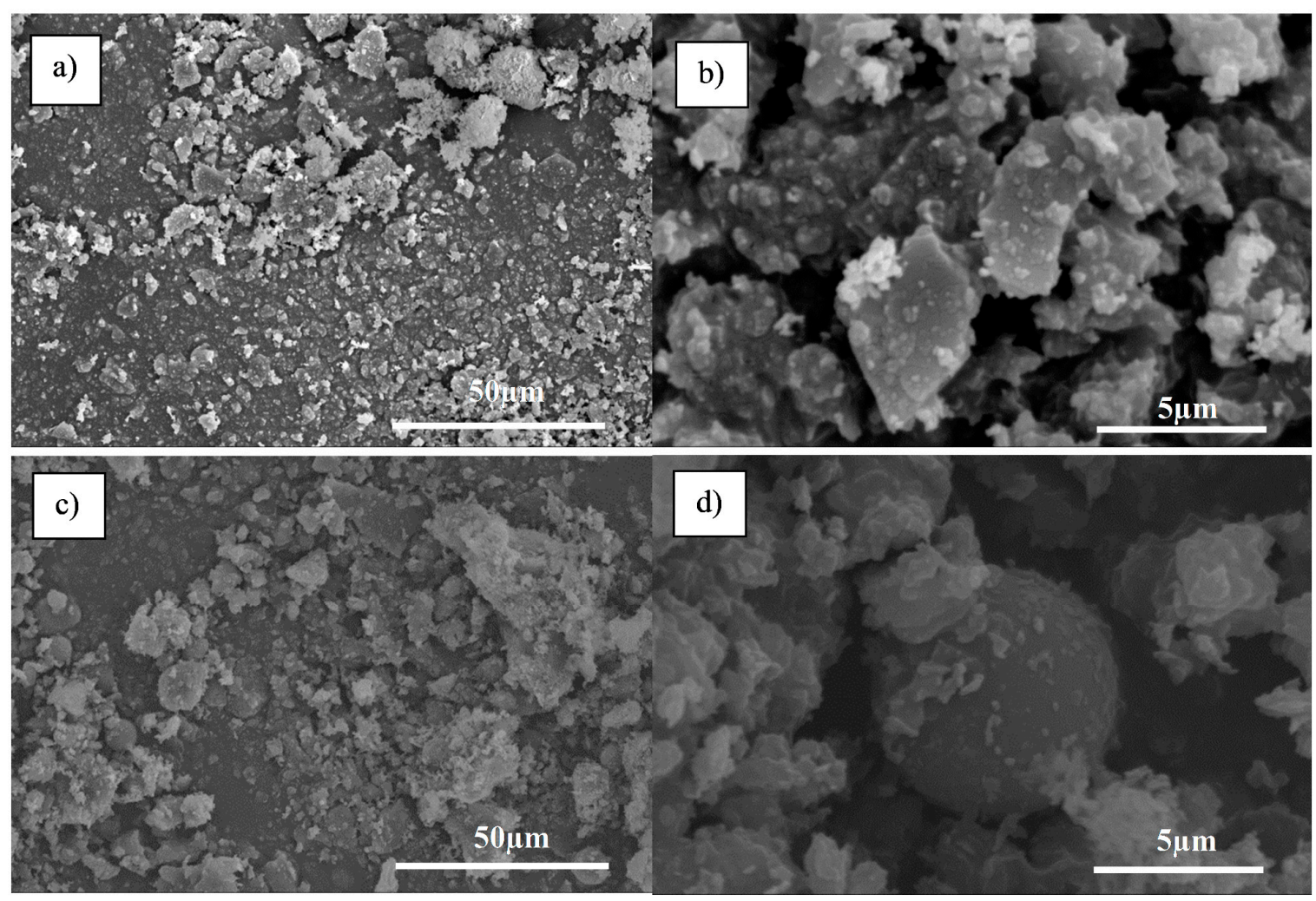

Figure 4. SEM images of calcined clays. $(\mathbf{a}, \mathbf{b})$ : Rotary kiln calcined clay. (c,d): Flash calcined clay.

\subsection{Mechanical Properties}

Firstly, compressive strength after 28 days was one of the criteria adopted to determine the appropriate GPC replacement rate by LC3 allowing to satisfy the Australian Standards AS3600 [37] requirements in chloride environments (i.e. $45 \mathrm{MPa}$ characteristic compressive strength). The second criteria adopted was to maintain an early age compressive strength similar to that of reference GPC concrete. Based on these two criteria, 20wt.\% of GPC could be replaced by using the flash calcined clay with an amorphous content of $50.9 \mathrm{wt} . \%$. However, $44 \mathrm{wt} . \%$ of GPC could be replaced by using the rotary kiln calcined clay with an amorphous content of $78.8 \mathrm{wt} . \%$. The influence of calcined clay reactivity on cement-based materials performance was investigated in previous studies. Tironi et al. [33] assessed the influence of calcined clays reactivity (i.e. amorphous content) on mechanical and physical properties of mortars. Results indicated that different calcined clay reactivity led to different replacement levels of Portland cement to maintain similar compressive strength, which are consistent with results presented in this paper. Tironi et al. [19] used calcined clay with 40wt.\% amorphous content in mortar and reported a comparable compressive strength at 28 days of mortar with LC3 replacement level at $20 \mathrm{wt} . \%$, which is consistent with results obtained on the flash calcined clay used in this study. $40 \mathrm{wt} . \%$ substitution rate using this low-grade calcined clay and limestone led to a lower compressive strength than that of reference Portland cement concrete up to 90 days [19].

The time-dependent compressive strength of LC3-F, LC3-R and reference GPC concretes is presented in Figure 5. GPC exhibited the highest compressive strength from 7 days to 28 days, but the difference with LC3-based concretes was low. LC3-F show higher compressive strength at 1 day and 3 days than both GPC and concrete with rotary kiln calcined clay (LC3-R). Subsequently, the compressive strength of LC3-R concrete increased rapidly from 3 days to 14 days overpassing LC3-F. The compressive strength of LC3-F and LC3-R concretes was relatively similar at 28 days reaching 49.33 MPa and 49.66 MPa, respectively, which were similar to that of GPC. All concretes achieved an average compressive strength meeting the Australian Standard AS3600 [37] minimum requirement for concrete to be used in chloride environments of $45 \mathrm{MPa}$ characteristic compressive strength. 


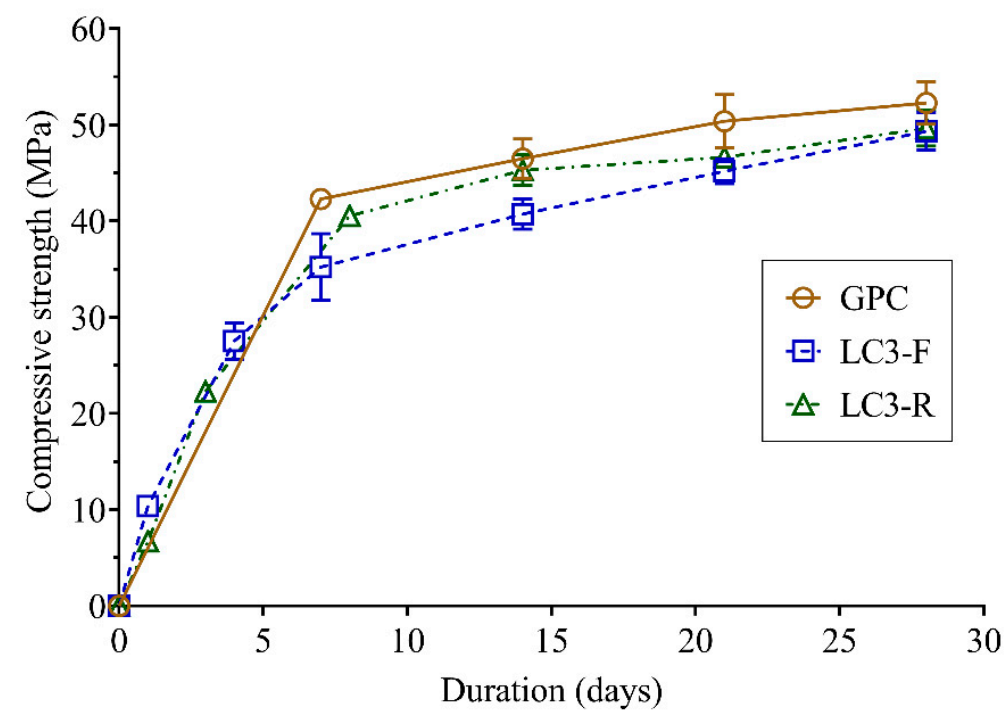

Figure 5. Strength development of concretes until 28 days.

The elastic modulus of concrete at 28 days is shown in Table 4. GPC concrete exhibited the lowest elastic modulus of 31.1 GPa among three concretes. LC3-F and LC3-R concretes presented a modulus of elasticity of $34.5 \mathrm{GPa}$ and $41.0 \mathrm{GPa}$ respectively, which was $10.9 \%$ and $31.8 \%$ higher than that of GPC concrete. This reveals that LC3 concrete may offer a significant advantage over Portland cement concretes for structural applications where high elastic modulus is required. Dhandapani et al. [20] reported as well higher concrete elastic modulus when replacing $50 \mathrm{wt} . \%$ of the binder by LC 3 , but the difference was smaller than that of this study. A higher LC3 concrete elastic modulus compared to Portland cement concrete was reported previously by the authors using the same flash calcined clay [18].

Table 4. Elastic modulus of concretes.

\begin{tabular}{cc}
\hline Concrete Types & Elastic Modulus at 28 Days (GPa) \\
\hline GPC & $31.1 \pm 0.9$ \\
LC3-F & $34.5 \pm 0.5$ \\
LC3-R & $41.0 \pm 0.4$ \\
\hline
\end{tabular}

\subsection{Bulk Diffusion}

The bulk diffusion test protocol following ASTM C1556 is a long-term test and its mechanism replies on the slow non-steady-state chloride ion diffusion from external $\mathrm{NaCl}$ solution into the concrete matrix. The total chloride profiles after the bulk diffusion test of the three concrete types are illustrated in Figure 6. LC3-based concretes exhibited higher chloride content in comparison with GPC concrete, near the exposure surface. To be specific, LC3-F and LC3-R concretes showed a higher chloride content from the exposure surface to $9 \mathrm{~mm}$ and $5 \mathrm{~mm}$ depth than that of reference concrete, respectively. This may be attributed by the function of surface porosity in different concrete types [53,54], but further studies are required to understand this phenomenon in the LC3 concretes. However, the chloride content of LC3-F and LC3-R concretes decreased rapidly throughout the concrete depth and was negligible after $15 \mathrm{~mm}$ from the exposure surface. The GPC concrete presented a gradual decline in chloride content from the exposure surface to a depth of $25 \mathrm{~mm}$. 


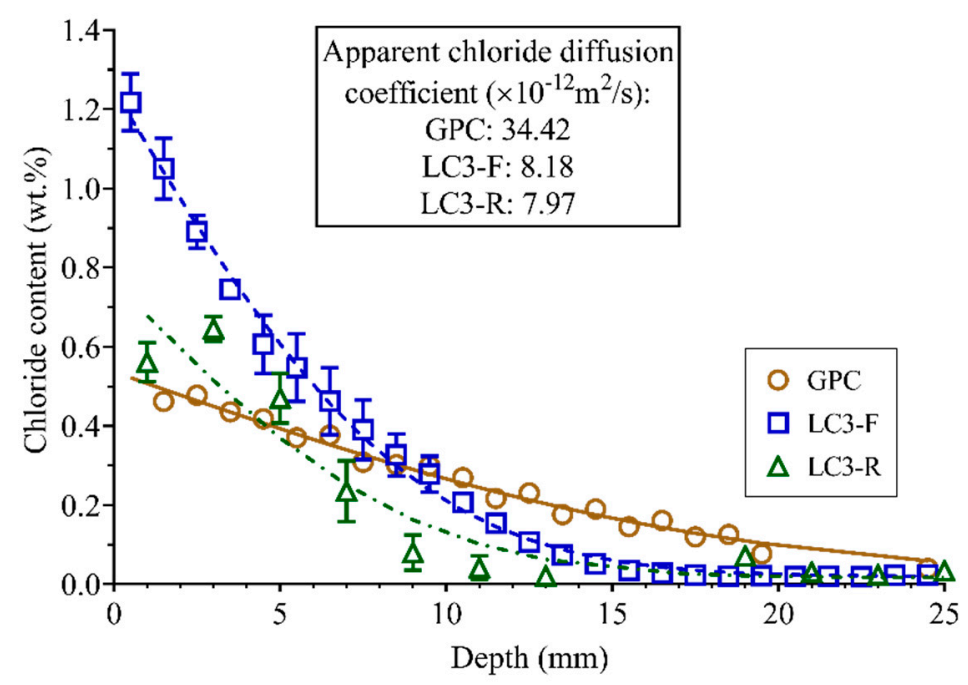

Figure 6. Total chloride content profile and chloride diffusion coefficient from the bulk diffusion test (ASTM C1556).

The apparent chloride diffusion coefficients of all concretes used in the study are presented in Figure 6. They were calculated by using non-linear regression analysis and the method of least squares with a duration of 35 days in sodium chloride solution. LC3-based concrete obtained significantly lower coefficients in comparison with reference concrete. GPC concrete exhibited the highest apparent chloride diffusion coefficient at $34.42 \times 10^{-12} \mathrm{~m}^{2} / \mathrm{s}$. LC3-F and LC3-R apparent diffusion coefficients were only $8.18 \times 10^{-12} \mathrm{~m}^{2} / \mathrm{s}$ and $7.97 \times 10^{-12} \mathrm{~m}^{2} / \mathrm{s}$ respectively. Sui et al. [30] revealed that LC3 mortar obtained the lowest apparent chloride diffusion coefficient among different binary and ternary cementitious materials. Although the bulk diffusion test was criticised due to the oversimplified mathematical expressions of Fick's second law of diffusion and non-steady-state chloride diffusion [55,56], it has been widely used as an indicator to predict the service life of concrete structure in chloride environment [57]. Pillai et al. [58] also reported a remarkably low chloride diffusion coefficient of LC3 concrete in comparison with pulverised fuel ash and ordinary Portland cement (OPC) concrete. Moreover, the estimation of service life of LC3 concrete was 8-10 times longer than that of OPC concrete and similar to pulverised fuel ash concrete up to 150 years [32,58].

The significantly low apparent chloride diffusion coefficient of LC3 concrete can be explained by its enhanced chloride binding capacity and the refinement of pore structure and pore solution. A previous study revealed that metakaolin and limestone in binder produced more chloride bound as Friedel's salt than that of OPC paste, which indicates a better chloride binding capacity [28]. The excellent chloride ion transport resistance of LC3 concrete was also reported by Maraghechi et al. [29]. The better performance of LC3-based materials was predominantly attributed by the refined pore structure rather than the chloride binding capacity in different pastes and mortars. However, after examining the relationship between different microstructural parameters, Sui et al. [30] suggested that the chloride binding was a more important parameter than pore structure, contributing to the reduction in apparent chloride diffusion coefficients. Moreover, the presence of limestone in calcined clay samples enhance the chloride resistance whilst it showed little effect on slag and fly ash samples [30]. A decrease of alkalis content in pore solution led to a decrease of the apparent chloride diffusion coefficient. Although the effect of pore solution on the chloride transport resistance has been not fully understood, there was a clear relationship between total alkalis in pore solution and diffusion coefficient [30]. In previous studies conducted by the authors $[18,22,26]$, LC3 concrete using the same flash calcined clay presented refined pore structure from the mercury intrusion porosimetry (MIP) test. Specifically, LC3 replacement decreased the quantity of pores more than $0.1 \mu \mathrm{m}$ and increased the number of pores less than $0.01 \mu \mathrm{m}$. In addition, the total alkalis content of LC3 pastes was lower that all OPC concrete due to the dilution effect of limestone and flash calcined clay. The low apparent chloride diffusion coefficient of LC3 
concretes in this study confirms the high chloride diffusion resistance and is consistent with the high surface resistivity reported in a previous study [18]. A study of LC3 concrete microstructure is currently in progress to investigate the influence of pore structure, pore solution compositions and chloride binding capacity on the chloride diffusion resistance of LC3 concretes with different calcined clays.

Gbozee et al. [36] revealed that the chloride diffusion resistance of calcined clay mortars mainly depends on the phase assemblage rather than the available aluminium or calcined clay replacement content in the binder. In addition, calcined clay primarily contributes to the chloride binding capacity of the LC3 system, as reported in previous studies [28-30]. Experimental results in this paper confirm that high chloride diffusion resistance may be achieved by using optimum calcined clay and limestone substitution level in concrete. To be specific, a relatively similar apparent chloride diffusion coefficient was observed in both LC3-F concrete and LC3-R concrete at $8.18 \times 10^{-12} \mathrm{~m}^{2} / \mathrm{s}$ and $7.97 \times 10^{-12} \mathrm{~m}^{2} / \mathrm{s}$, regardless the types of calcined clay. The two calcined clays used in this study present very different reactivity but achieved the same level of chloride diffusion resistance by using appropriate replacement rates, which may be attributed to the similar phase assemblage in the two LC 3 concretes.

\section{Conclusions}

The study investigated the characteristics of two calcined clays and their influence on the mechanical properties and chloride diffusion resistance of limestone calcined clay cement concrete.

One calcined clay was produced from the flash calcination, the other from rotary kiln calcination. The following outcomes can be reported from the test results:

(1) The chemical and mineralogical compositions of the two calcined clays were significantly different. Most importantly, the amorphous phase content was $50.9 \mathrm{wt} . \%$ and $78.8 \mathrm{wt} . \%$ in the flash calcined clay and the rotary kiln calcined clay respectively. The amorphous content in calcined clay was consistent with the amount of $\mathrm{Al}_{2} \mathrm{O}_{3}$ and $\mathrm{SiO}_{2}$ determined by $\mathrm{XRF}$ analysis.

(2) 28 days compressive strength was adopted to determine the appropriate GPC replacement rate by LC3 allowing to satisfy Australian Standards AS3600 [37] requirements in chloride environments (i.e. $45 \mathrm{MPa}$ characteristic compressive strength). Based on different activity of calcined clays, $20 \mathrm{wt} . \%$ of GPC could be replaced by using the flash calcined clay with an amorphous content of $50.9 \mathrm{wt} . \%$. However, $44 \mathrm{wt} . \%$ of GPC could be replaced by using the rotary kiln calcined clay with an amorphous content of $78.8 \mathrm{wt} . \%$. The early age compressive strength of LC3 concrete was similar to that of reference concrete.

(3) The apparent chloride diffusion coefficient of LC3 concretes was more than four times lower than that of reference concrete. A study is currently in progress to evaluate microstructure factors contributing to the better chloride diffusion resistance of LC3 concretes. The apparent chloride diffusion coefficients of the two LC3 concretes were similar despite different replacement levels of calcined clays and limestone. Importantly, this result reveals that LC3 concrete chloride diffusion resistance may be marginally dependent on the types of calcined clay used if using an optimum Portland cement replacement rate based on compressive strength requirements in chloride environments.

(4) In conclusion, the type of calcined clay used could affect the Portland cement replacement rate in LC3 binder but the similar LC3 concrete mechanical properties and chloride diffusion resistance can be achieved with an appropriate replacement rate.

Author Contributions: Conceptualization, Q.D.N. and A.C.; data curation, Q.D.N. and S.A.; investigation, Q.D.N. and S.A.; methodology, Q.D.N. and S.A.; project administration, A.C.; resources, A.C.; supervision, A.C.; validation, S.A.; visualization, Q.D.N.; writing-original draft, Q.D.N.; writing-review \& editing, Q.D.N., S.A. and A.C. All authors have read and agreed to the published version of the manuscript.

Funding: This research was funded by Australian Research Council (ARC), grant number ARC Discovery Project DP160104731.

Acknowledgments: The assistance of the laboratory staff is acknowledged here.

Conflicts of Interest: The authors declare no conflict of interest. 


\section{References}

1. Scrivener, K.L.; John, V.M.; Gartner, E.M. Eco-efficient cements: Potential economically viable solutions for a low-CO2 cement-based materials industry. Cem. Concr. Res. 2018, 114, 2-26. [CrossRef]

2. Madlool, N.A.; Saidur, R.; Hossain, M.S.; Rahim, N.A. A critical review on energy use and savings in the cement industries. Renew. Sustain. Energy Rev. 2011, 15, 2042-2060. [CrossRef]

3. Schneider, M. The cement industry on the way to a low-carbon future. Cem. Concr. Res. 2019, 124, 105792. [CrossRef]

4. United Nations. World Urbanization Prospects: The 2011 Revision; Department of Economic and Social Affairs: New York, NY, USA, 2011.

5. Angst, U.M. Challenges and opportunities in corrosion of steel in concrete. Mater. Struct. 2018, 51, 4. [CrossRef]

6. Tinnea, J. Corrosion Control Plan for Bridges; A NACE International White Paper; NACE International: Houston, TX, USA, 2012.

7. Bertolini, L.; Elsener, B.; Pedeferri, P.; Redaelli, E.; Polder, R.B. Corrosion of Steel in Concrete: Prevention, Diagnosis, Repair, 2nd ed.; Wiley-VCH Verlag GmbH \& Co. KGaA: Weinheim, Germany, 2013.

8. Andrade, C. Propagation of reinforcement corrosion: Principles, testing and modelling. Mater. Struct. 2018, 52, 2. [CrossRef]

9. Favier, A.; De Wolf, C.; Scrivener, K.; Habert, G. A Sustainable Future for the European Cement and Concrete Industry: Technology Assessment for Full Decarbonisation of the Industry by 2050; ETH Zurich: Zurich, Switzerland, 2018.

10. Yoshioka, K.; Obata, D.; Nanjo, H.; Yokozeki, K.; Torichigai, T.; Morioka, M.; Higuchi, T. New Ecological Concrete that Reduces CO2 Emissions Below Zero Level New Method for CO2 Capture and Storage. Energy Procedia 2013, 37, 6018-6025. [CrossRef]

11. Scrivener, K.; Martirena, F.; Bishnoi, S.; Maity, S. Calcined clay limestone cements (LC3). Cem. Concr. Res. 2018, 114, 49-56. [CrossRef]

12. San Nicolas, R.; Cyr, M.; Escadeillas, G. Performance-based approach to durability of concrete containing flash-calcined metakaolin as cement replacement. Constr. Build. Mater. 2014, 55, 313-322. [CrossRef]

13. San Nicolas, R.; Cyr, M.; Escadeillas, G. Characteristics and applications of flash metakaolins. Appl. Clay Sci. 2013, 83, 253-262. [CrossRef]

14. Lothenbach, B.; Le Saout, G.; Gallucci, E.; Scrivener, K. Influence of limestone on the hydration of Portland cements. Cem. Concr. Res. 2008, 38, 848-860. [CrossRef]

15. Mishra, G.; Emmanuel, A.C.; Bishnoi, S. Influence of temperature on hydration and microstructure properties of limestone-calcined clay blended cement. Mater. Struct. 2019, 52, 91. [CrossRef]

16. Cancio Díaz, Y.; Sánchez Berriel, S.; Heierli, U.; Favier, A.R.; Sánchez Machado, I.R.; Scrivener, K.L.; Martirena Hernández, J.F.; Habert, G. Limestone calcined clay cement as a low-carbon solution to meet expanding cement demand in emerging economies. Dev. Eng. 2017, 2, 82-91. [CrossRef]

17. Antoni, M.; Rossen, J.; Martirena, F.; Scrivener, K. Cement substitution by a combination of metakaolin and limestone. Cem. Concr. Res. 2012, 42, 1579-1589. [CrossRef]

18. Nguyen, Q.D.; Khan, M.S.H.; Castel, A. Engineering Properties of Limestone Calcined Clay Concrete. J. Adv. Concr. Technol. 2018, 16, 343-357. [CrossRef]

19. Tironi, A.; Scian, A.N.; Irassar, E.F. Blended Cements with Limestone Filler and Kaolinitic Calcined Clay: Filler and Pozzolanic Effects. J. Mater. Civ. Eng. 2017, 29, 04017116. [CrossRef]

20. Dhandapani, Y.; Sakthivel, T.; Santhanam, M.; Gettu, R.; Pillai, R.G. Mechanical properties and durability performance of concretes with Limestone Calcined Clay Cement (LC3). Cem. Concr. Res. 2018, 107, 136-151. [CrossRef]

21. Medjigbodo, G.; Roziere, E.; Charrier, K.; Izoret, L.; Loukili, A. Hydration, shrinkage, and durability of ternary binders containing Portland cement, limestone filler and metakaolin. Constr. Build. Mater. 2018, 183, 114-126. [CrossRef]

22. Khan, M.S.H.; Nguyen, Q.D.; Castel, A. Performance of limestone calcined clay blended cement-based concrete against carbonation. Adv. Cem. Res. 2019, 0,1-11. [CrossRef] 
23. Shi, Z.G.; Lothenbach, B.; Geiker, M.R.; Kaufmann, J.; Leemann, A.; Ferreiro, S.; Skibsted, J. Experimental studies and thermodynamic modeling of the carbonation of Portland cement, metakaolin and limestone mortars. Cem. Concr. Res. 2016, 88, 60-72. [CrossRef]

24. Muzenda, T.R.; Hou, P.; Kawashima, S.; Sui, T.; Cheng, X. The role of limestone and calcined clay on the rheological properties of LC3. Cem. Concr. Compos. 2020, 107, 103516. [CrossRef]

25. Vizcaíno Andrés, L.M.; Antoni, M.G.; Alujas Diaz, A.; Martirena Hernández, J.F.; Scrivener, K.L. Effect of fineness in clinker-calcined clays-limestone cements. Adv. Res. 2015, 27, 546-556. [CrossRef]

26. Khan, M.S.H.; Nguyen, Q.D. Castel, Carbonation of Limestone Calcined Clay Cement Concrete; Springer: Dordrecht, The Netherlands, 2018; pp. 238-243.

27. Nguyen, Q.D.; Castel, A. Reinforcement corrosion in limestone flash calcined clay cement-based concrete. Cem.Concr. Res. 2020, 132, 106051. [CrossRef]

28. Shi, Z.G.; Geiker, M.R.; De Weerdt, K.; Ostnor, T.A.; Lothenbach, B.; Winnefeld, F.; Skibsted, J. Role of calcium on chloride binding in hydrated Portland cement-metakaolin-limestone blends. Cem. Concr. Res. 2017, 95, 205-216. [CrossRef]

29. Maraghec hi, H.; Avet, F.; Wong, H.; Kamyab, H.; Scrivener, K. Performance of Limestone Calcined Clay Cement (LC3) with various kaolinite contents with respect to chloride transport. Mater. Struct. 2018, 51, 125. [CrossRef]

30. Sui, S.; Georget, F.; Maraghechi, H.; Sun, W.; Scrivener, K. Towards a generic approach to durability: Factors affecting chloride transport in binary and ternary cementitious materials. Cem. Concr. Res. 2019, 124, 105783. [CrossRef]

31. Avet, F.; Scrivener, K. Influence of $\mathrm{pH}$ on the chloride binding capacity of Limestone Calcined Clay Cements (LC3). Cem. Concr. Res. 2020, 131, 106031. [CrossRef]

32. Yang, P.; Dhandapani, Y.; Santhanam, M.; Neithalath, N. Simulation of chloride diffusion in fly ash and limestone-calcined clay cement (LC3) concretes and the influence of damage on service-life. Cem. Concr. Res. 2020, 130, 106010. [CrossRef]

33. Tironi, A.; Castellano, C.C.; Bonavetti, V.L.; Trezza, M.A.; Scian, A.N.; Irassar, E.F. Kaolinitic calcined clays-Portland cement system: Hydration and properties. Constr. Build. Mater. 2014, 64, 215-221. [CrossRef]

34. Tironi, A.; Trezza, M.A.; Scian, A.N.; Irassar, E.F. Thermal analysis to assess pozzolanic activity of calcined kaolinitic clays. J. Therm. Anal. Calorim. 2014, 117, 547-556. [CrossRef]

35. Avet, F.; Scrivener, K. Investigation of the calcined kaolinite content on the hydration of Limestone Calcined Clay Cement (LC3). Cem. Concr. Res. 2018, 107, 124-135. [CrossRef]

36. Gbozee, M.; Zheng, K.; He, F.; Zeng, X. The influence of aluminum from metakaolin on chemical binding of chloride ions in hydrated cement pastes. Appl. Clay Sci. 2018, 158, 186-194. [CrossRef]

37. AS 3600: Concrete Structures; Standards Australia: Sydney, Australia, 2018.

38. AS 3972: General Purpose and Blended Cements; Standards Australia: Sydney, Australia, 2010.

39. ASTM C39/C39M-18: Standard Test Method for Compressive Strength of Cylindrical Concrete Specimens; ASTM International: West Conshohocken, PA, USA, 2018.

40. ASTM C469/C469M-14: Standard Test Method for Static Modulus of Elasticity and Poisson's Ratio of Concrete in Compression; ASTM International: West Conshohocken, PA, USA, 2014.

41. ASTM C1556-11a(2016): Standard Test Method for Determining the Apparent Chloride Diffusion Coefficient of Cementitious Mixtures by Bulk Diffusion; ASTM International: West Conshohocken, PA, USA, 2016.

42. ASTM C1152/C1152M-04(2012)e1: Standard Test Method for Acid-Soluble Chloride in Mortar and Concrete; ASTM International: West Conshohocken, PA, USA, 2012.

43. Noushini, A.; Castel, A.; Aldred, J.; Rawal, A. Chloride diffusion resistance and chloride binding capacity of fly ash-based geopolymer concrete. Cem. Concr. Compos. 2020, 105, 103290. [CrossRef]

44. Chen, Y.; Li, Z.; Chaves Figueiredo, S.; Çopuroğlu, O.; Veer, F.; Schlangen, E. Limestone and Calcined Clay-Based Sustainable Cementitious Materials for 3D Concrete Printing: A Fundamental Study of Extrudability and Early-Age Strength Development. Appl. Sci. 2019, 9, 1809. [CrossRef]

45. Badogiannis, E.; Papadakis, V.; Chaniotakis, E.; Tsivilis, S. Exploitation of poor Greek kaolins: strength development of metakaolin concrete and evaluation by means of k-value. Cem. Concr. Res. 2004, 34, 1035-1041. [CrossRef]

46. ASTM C618-19: Standard Specification for Coal Fly Ash and Raw or Calcined Natural Pozzolan for Use in Concrete; ASTM International: West Conshohocken, PA, USA, 2019. 
47. Claverie, M.; Martin, F.; Tardy, J.; Cyr, M.; De Parseval, P.; Grauby, O.; Le Roux, C. Structural and chemical changes in kaolinite caused by flash calcination: Formation of spherical particles. Appl. Clay Sci. 2015, 114, 247-255. [CrossRef]

48. Blissett, R.; Rowson, N. A review of the multi-component utilisation of coal fly ash. Fuel 2012, 97, 1-23. [CrossRef]

49. Ahmaruzzaman, M. A review on the utilization of fly ash. Prog. Energy Combust. Sci. 2010, 36, 327-363. [CrossRef]

50. Aboustait, M.; Kim, T.; Ley, M.T.; Davis, J.M. Physical and chemical characteristics of fly ash using automated scanning electron microscopy. Constr. Build. Mater. 2016, 106, 1-10. [CrossRef]

51. Cepuritis, R.; Garboczi, E.J.; Ferraris, C.F.; Jacobsen, S.; Sørensen, B.E. Measurement of particle size distribution and specific surface area for crushed concrete aggregate fines. Adv. Powder Technol. 2017, 28, 706-720. [CrossRef]

52. Odler, I. The BET-specific surface area of hydrated Portland cement and related materials. Cem. Concr. Res. 2003, 33, 2049-2056. [CrossRef]

53. Li, C.; Jiang, L.; Xu, N.; Jiang, S. Pore structure and permeability of concrete with high volume of limestone powder addition. Powder Technol. 2018, 338, 416-424. [CrossRef]

54. Ishida, T.; Iqbal, P.O.; Anh, H.T.L. Modeling of chloride diffusivity coupled with non-linear binding capacity in sound and cracked concrete. Cem. Concr. Res. 2009, 39, 913-923. [CrossRef]

55. Stanish, K.; Thomas, M. The use of bulk diffusion tests to establish time-dependent concrete chloride diffusion coefficients. Cem. Concr. Res. 2003, 33, 55-62. [CrossRef]

56. Luping, T.; Gulikers, J. On the mathematics of time-dependent apparent chloride diffusion coefficient in concrete. Cem. Concr. Res. 2007, 37, 589-595. [CrossRef]

57. Shafikhani, M.; Chidiac, S. Quantification of concrete chloride diffusion coefficient-A critical review. Cem. Concr. Compos. 2019, 99, 225-250. [CrossRef]

58. Pillai, R.G.; Gettu, R.; Santhanam, M.; Rengaraju, S.; Dhandapani, Y.; Rathnarajan, S.; Basavaraj, A.S. Service life and life cycle assessment of reinforced concrete systems with limestone calcined clay cement (LC3). Cem. Concr. Res. 2019, 118, 111-119. [CrossRef] 